\title{
Are Yam Farmers Aware and Willing to Adopt the Aeroponics Farming System in Oyo State, Nigeria?
}

\author{
Abimbola Oluyemisi Adepoju, Oluwadamilola Christiana Olaseni \\ Department of Agricultural Economics, University of Ibadan, Nigeria
}

\begin{abstract}
Despite the immense returns of new agricultural technologies to increase agricultural productivity and meet rising food demand, there is a lag in the adoption of these technologies by farmers. The aeroponics system is one of such innovative technologies implemented for seed yam propagation. This study assessed the awareness and the determinants of the willingness of yam farmers to adopt the aeroponics farming system, employing the likert scale and the logit regression model. Results showed that more than three-fifths of the farmers had never heard of the aeroponics farming system but were willing to adopt it for yam and seed yam propagation, although high cost of capital required for adoption was a major constraint. Key determinants of farmers' awareness of the aeroponics system include gender, age, education, membership of cooperative society, monthly income and access to extension agent, while the main factors influencing its adoption were marital status, age, access to credit, membership of cooperative society, farm size and income. Efforts at dissemination of aeroponics farming system for increased productivity should be intensified for its effective adoption by the farmers.
\end{abstract}

\section{Keywords}

The aeroponics system, yam farmers, awareness, perception, willingness to adopt.

Adepoju, A. O. and Olaseni, O. C. (2021) "Are Yam Farmers Aware and Willing to Adopt the Aeroponics Farming System in Oyo State, Nigeria?", AGRIS on-line Papers in Economics and Informatics, Vol. 13, No. 1, pp. 3-13. ISSN 1804-1930. DOI 10.7160/aol.2021.130101.

\section{Introduction}

Yam (Dioscorea spp.) is a major staple predominantly produced and consumed in West and Central Africa. Yams are multi-species crops with over 600 species, out of which six are socially and economically important for food, income, medicine and socio-cultural practices (IITA, 2009). Some of the edible yam species are water yam (Dioscorea alata), white yam (Dioscorea rotundata), yellow yam (Dioscorea cayanensis), Chinese yam (Dioscorea polystachya) and threeleaf yams (Awoniyi and Omonona, 2006). In terms of production, Nigeria is the largest producer of yam in the world followed by Ghana, Cote D'Ivoire, Benin, Togo and Cameroon (FAO, 2013). As a major staple food, yam plays an important role in the nutrition of millions of people in the world regardless of the form (Umar et al., 2016). Economically, yam is important in local commerce in Nigeria and accounts for about $32 \%$ of farm income (Chukwu and Ikwelle, 2000). It also serves as a major source of foreign exchange earnings as it is used as a raw material in starch industries and pharmaceutical companies. Furthermore, the agricultural value chain of yam offers vast employment opportunities for millions of Nigerians (Verter and Becvarova, 2014). Therefore, producing large quantities of high quality mini tubers at minimal cost is essential for an economically viable supply of yam seed. This is important not only to maintain a steady supply of yam and yam seed, improve food security and increase foreign exchange earnings, but also to improve food performance of yam particularly in the face of climate change (Aighewi et al., 2015). Climate change is the primary determinant of agricultural productivity which is expected to influence yam production, hydrologic balances, input supplies and other components of agricultural systems. This situation deepens the challenges in agriculture, thus making agricultural and food systems unsustainable as well as hunger and poverty eradication a far-ending global objective. Hence, addressing 
the issues of staple food production should be paramount as studies revealed that by 2050 , the world population is expected to surpass ten billion mark, 34\% higher than the current world population with much of the population increase occurring in developing nations (Cohen, 2003). However, the sustainable growth of the agricultural sector critically depends on the adoption of improved, scale-appropriate and ecofriendly technologies, implying that the role of adoption of new technologies in agriculture is fundamental to agricultural growth (Mottaleb, 2018).

Yam production in Nigeria is substantially low and cannot meet the growing demand at its present level of use. This can be attributed to some major challenges such as weed pressure, decline in soil fertility due to nutrient depletion by leaching, and the usage of traditional technology for the production of yam seed (Manyong et al., 2001). This situation is exacerbated by low multiplication rate of yam seeds, which is worsened by its long growth cycle and dormancy period. The low rate of multiplication of yam seeds and the use of edible tubers ( $25 \%-30 \%$ of those planted in the previous planting season) for propagation make yam seedlings very expensive (Katung et al., 2006). This results in the use of mixed genotypes, pre-infected seed yam and farmlands, thus causing a build-up of an array of fungal, nematode, bacterial and diseases and pests which results to about $50 \%-90 \%$ yield reduction. The provision of fresh and clean yam supply for the fast-growing population using traditional farming methods may remain insufficient. Hence, the need for a comprehensive and sufficient viable alternative such as the hydroponics and aeroponics system.

The International Union of Soil-Less Culture defines aeroponics as a system where roots are grown continuously or discontinuously in an environment saturated with fine drops (a mist or aerosol) of nutrient solution. Aeroponics is the science of plant cultivation without incorporation of the soil or a substrate culture. In aeroponics system, plants grow in the air with the assistance of an artificial support with no soil or substrate required to support the plant (Osvald et al., 2001). The system has shown promising returns in various countries and has been recommended as the most efficient, useful, significant, economical and convenient plant growing system than soil and other soil-less methods. The aeroponics system is one of the new technologies implemented for seed yam propagation through the project known as "Yam Improvement for Income and Food Security in West Africa (YIIFSWA) (Maroya et al., 2014). Unfortunately, many African nations, especially Nigeria, are lagging behind in the adoption and implementation of innovative technologies capable of turning the present situation around. This predicament is further worsened by the farmers' unlikely attitude to adopt innovations perceived to be of benefit.

Numerous studies on yam in Nigeria have laid emphasis on the production, demographics of farmers and farming households, as well as the present state, challenges and constraints facing the production of the crop. Studies have outlined several constraints facing the production of yam (Idumah et al., 2014; Verter and Bečvářová, 2015; Bassey 2017), as well as awareness, perception and willingness of farmers towards the use of innovation and technology in agricultural production (Oladele and Fawole, 2007; Edeogbon et al., 2008; Simtowe et al., 2012; Kolawole et al., 2012; Ochola et al., 2013; Mukadasi and Lusiba, 2016; Nain et al., 2017). However, there is a dearth of literature assessing the link between the awareness, perception and willingness of farmers towards the adoption of aeroponics system of yam production. Considering the foregoing, this paper will contribute to scarce literature on the awareness and willingness to adopt the aeroponics farming system by farmers. This study aims to assess the level of awareness of yam farmers and their willingness to adopt the aeroponic farming system, as well as the extent to which socioeconomic and other factors are associated with their perception and willingness to adopt the farming technology. Constraints to the adoption of the aeroponics farming system were also examined.

\section{Materials and methods}

The population for the study consisted of all yam farmers in the Local Government Area. The sample included 150 selected farmers using the Yamane (1967) formula at a 95\% confidence level and $\pm 5 \%$ precision. The selection procedure was a multistage sampling technique. The first stage was the purposive selection of Irepo Local Government Area (LGA) because of the prevalence of yam farmers in the LGA. In the second stage, five wards were randomly selected from the 10 wards in the LGA. The third stage involved the random 
selection of 30 farmers each from the 5 wards which amounted to a total of 150 yam farming households. However, as a result of incomplete information, data from 133 respondents were used for analysis. A five-point Likert scale was used to assess the level of awareness and perception of the aeroponics farming system following the studies of Bagheri (2010), Ajibefun and Fatuase (2014) and Okoro and Ajieh (2015).

To examine the constraints encountered by yam farmers in the adoption of the aeroponic farming system, the mean of each constraint was determined by summing up the values picked by all the respondents, dividing by the total number of respondents and then ranking in order of magnitude. The awareness and willingness to adopt an innovation refers to a binary variable that takes 1 if the farmer is aware and willing to adopt the innovation and 0 if otherwise respectively. In this study, the binary variable defines the awareness and willingness to adopt the aeroponics farming system. The dependent variables: awareness or willingness to adopt are treated as 1 if the farmer $i$ is aware or will adopt the aeroponics system and 0 if otherwise respectively. The binary logistic regression model, which studies the association between a categorical dependent variable and a set of independent (explanatory) variables, is appropriate given its computational simplicity and that awareness and the willingness to adopt fits into a dichotomous choice (Udimal et al., 2017 and Ntshangase et al., 2018). The model requires a binary dependent variable, independence of the observations and little or no multicollinearity among the independent variables. The model for this study is specified as follows:

$$
\begin{aligned}
P i(Y i & =1)=P i=F(Z i)= \\
& =F\left(\alpha+\sum b i X i\right)=\frac{1}{1+e^{-z}}
\end{aligned}
$$

Where $P_{i}$ is the probability that a farmer is aware of the aeroponic system and is willing to adopt the farming system respectively; $X_{i}$ represents explanatory variables; and $\alpha$ and $\beta$ are parameters to be estimated.

$$
\begin{aligned}
\operatorname{Prob}(Y i=0) & =1-\operatorname{Prob}(Y i=1)= \\
& =(1-P i)=\frac{1}{1+e^{z}}
\end{aligned}
$$

From Equations (1) and (2), we get

$$
\frac{\operatorname{Prob}(Y i=1)}{\operatorname{Prob}(Y i=0)}=\frac{P i}{1-P i}=e^{Z}
$$

Where $P_{i}$ is the probability that $Y_{i}$ takes the value 1 and then $\left(1-P_{i}\right)$ is the probability that $Y_{i}$ is 0 and $e$ is the exponential constant. Equation 3 is the ratio of the probability that a respondent is aware or will adopt the aeroponics system to the probability that he is not aware or will not adopt the aeroponics farming system.

Therefore, taking the natural $\log$ of both sides of Equation (3), we get

$$
\begin{aligned}
Z i & =\operatorname{In}\left(\frac{P i\left(Y_{i}=1\right.}{1-P i\left(Y_{i}=1\right.}\right)=\log \text { odds }=\operatorname{logit} Y= \\
& =\beta_{0}+\beta_{1} X_{1}+\ldots \beta n X n
\end{aligned}
$$

Where $Y=$ dependent variable (awareness/ willingness to adopt); $\beta_{0}=$ intercept; $\beta_{1} \ldots \beta_{n}=$ coefficients of the independent variables; $X_{1}, \ldots X_{n}=$ the independent variables.

\section{Results and discussion}

Table 1 presents the socioeconomic characteristics of the farmers. Nine out of ten of the farmers were males. Majority of the farmers were married and between the ages of 31 and 60 years with a mean age of $50.1 \pm 12.4$ years. A larger percentage of the respondents had one form of education or the other and were engaged in farming as their primary occupation with household sizes of between 6 and 10 persons per household respectively. The mean household size stood at about $11.0 \pm 7.0$ persons per household. About four-fifths of the respondents had no access to credit with more than two-fifths being members of one cooperative society or the other. Almost all the respondents had access to general agricultural information. The average farm size and farm size under cultivation of yam stood at $2.9 \pm 1.0$ and $2.1 \pm 0.9$ hectares respectively. Average monthly income was $\$ 58,500.00 \pm 46,377.50$ with more than three-fifths of the respondents having less than 20 years of farming experience. The mean years of farming experience of the respondents was $20.7 \pm 15.2$ years. The traditional system of farming was predominant in the study area with less than one percent indicating the use of the aeroponics farming system.

The level of awareness of respondents about the aeroponics farming system in the study area is presented in Table 2. The level of awareness of the yam farmers was obtained by summing up the values gotten from the responses; and deriving the mean score, standard deviation of each attribute was calculated and interpreted. The results revealed that the respondents' awareness about the aeroponics farming system was generally low as about seven out of ten respondents had 
never heard of the aeroponics farming system. However, about one-tenths were aware but with little knowledge of the operations of the aeroponics system. Only $15.8 \%$ of the farmers showed adequate knowledge of the system.

\begin{tabular}{|c|c|c|c|c|}
\hline $\begin{array}{l}\text { Socioeconomic } \\
\text { Characteristics }\end{array}$ & Frequency & Percentage & Mean & $\begin{array}{l}\text { Standard } \\
\text { Deviation }\end{array}$ \\
\hline \multicolumn{5}{|l|}{ Gender } \\
\hline Male & 123 & 92.5 & & \\
\hline Female & 10 & 7.5 & & \\
\hline \multicolumn{5}{|l|}{ Age(years) } \\
\hline$<30$ & 7 & 5.3 & 50.1 & 12.4 \\
\hline $31-60$ & 95 & 71.4 & & \\
\hline$>61$ & 31 & 23.3 & & \\
\hline \multicolumn{5}{|l|}{ Marital Status } \\
\hline Single & 4 & 3.0 & & \\
\hline Married & 123 & 92.5 & & \\
\hline Widowed & 4 & 3.0 & & \\
\hline Divorced & 2 & 1.5 & & \\
\hline \multicolumn{5}{|l|}{$\begin{array}{l}\text { Educational } \\
\text { Status }\end{array}$} \\
\hline No formal & 38 & 28.6 & & \\
\hline Primary & 27 & 20.3 & & \\
\hline Secondary & 35 & 26.3 & & \\
\hline Tertiary & 33 & 24.8 & & \\
\hline \multicolumn{5}{|l|}{$\begin{array}{l}\text { Primary } \\
\text { Occupation }\end{array}$} \\
\hline Farming & 133 & 85.0 & & \\
\hline Trading & 9 & 6.8 & & \\
\hline Civil Servant & 6 & 4.5 & & \\
\hline Artisan & 5 & 3.8 & & \\
\hline \multicolumn{5}{|l|}{ Household Size } \\
\hline $1-5$ & 39 & 29.3 & 11.3 & 6.8 \\
\hline 6-10 & 43 & 32.3 & & \\
\hline $11-15$ & 29 & 21.8 & & \\
\hline$>15$ & 22 & 16.5 & & \\
\hline \multicolumn{5}{|l|}{ Credit Access } \\
\hline Yes & 29 & 21.8 & & \\
\hline No & 104 & 78.2 & & \\
\hline \multicolumn{5}{|l|}{$\begin{array}{l}\text { Cooperative } \\
\text { Membership } \\
\end{array}$} \\
\hline Yes & 59 & 44.4 & & \\
\hline No & 74 & 55.6 & & \\
\hline \multicolumn{5}{|l|}{$\begin{array}{l}\text { Access to } \\
\text { Information }\end{array}$} \\
\hline Yes & 128 & 96.2 & & \\
\hline No & 5 & 3.8 & & \\
\hline \multicolumn{5}{|l|}{ Farm Size } \\
\hline$<1$ & 12 & 9.0 & 2.9 & 1.0 \\
\hline $1-4$ & 40 & 30.1 & & \\
\hline $5-8$ & 26 & 19.5 & & \\
\hline$>8$ & 55 & 41.4 & & \\
\hline
\end{tabular}

Source: research findings

Table 1: Socioeconomic characteristics of respondents (to be continued).

\begin{tabular}{|l|r|r|r|r|}
\hline $\begin{array}{l}\text { Socioeconomic } \\
\text { Characteristics }\end{array}$ & Frequency & Percentage & Mean & $\begin{array}{r}\text { Standard } \\
\text { Deviation }\end{array}$ \\
\hline Yam Farm Size & & & & \\
\hline$<1$ & 32 & 24.1 & 2.1 & 0.9 \\
\hline $1-4$ & 70 & 52.6 & & \\
\hline $5-8$ & 13 & 9.8 & & \\
\hline$>8$ & 18 & 13.5 & & \\
\hline $\begin{array}{l}\text { Monthly } \\
\text { Income (naira) }\end{array}$ & & & & \\
\hline \multicolumn{1}{|c|}{$<1000000$} & 122 & 91.7 & 58500.00 & 46377.50 \\
\hline $100001-200000$ & 8 & 6.0 & & \\
\hline \multicolumn{1}{|c|}{$>200001$} & 3 & 2.3 & & \\
\hline $\begin{array}{l}\text { Farming } \\
\text { Experience }\end{array}$ & & & & \\
\hline$<20$ & 29 & 21.8 & & \\
\hline $21-40$ & 22 & 16.5 & & \\
\hline$>41$ & 132 & 99.2 & & \\
\hline $\begin{array}{l}\text { Farming } \\
\text { System }\end{array}$ & & & & \\
\hline Aeroponics & & & & \\
\hline Soil based & & & & \\
\hline Sourc: resa. & & & & \\
\hline
\end{tabular}

Source: research findings

Table 1: Socioeconomic characteristics of respondents (continuation)

\begin{tabular}{lcc}
\hline Level of awareness & Frequency & Percentage \\
\hline High & 21 & 15.8 \\
Medium & 16 & 12.0 \\
Low & 96 & 72.2 \\
\hline Total & 133 & 100.0 \\
\hline
\end{tabular}

Source: research findings

Table 2: Level of awareness of the aeroponics farming system.

Information presented in Table 3 shows the respondents level of perception of the aeroponics farming system. Results revealed that majority of the respondents had a moderate to strong level of perception of the aeroponics system while only a minority of the respondents had a weak level of perception about the aeroponics system.

\begin{tabular}{lcc}
\hline Category of Perception & Frequency & Percentage \\
\hline Strong & 34 & 25.6 \\
Moderate & 80 & 60.2 \\
Weak & 19 & 14.3 \\
\hline Total & 133 & 100.0 \\
\hline
\end{tabular}

Source: research findings

Table 3: Respondents level of perception of the aeroponics farming system.

The information on Table 4 shows the perception of the respondents towards several attributes of the farming system. The respondents perceived 9 statements in favour of the aeroponics farming system out of 12 statements used to ascertain their perceptions. The nine statements include: the system allows for increased yam and yam seedlings multiplication; the system requires less 


\begin{tabular}{|c|c|c|c|c|c|c|c|c|c|c|}
\hline \multirow{2}{*}{ Perception Attributes } & \multicolumn{2}{|c|}{ SA } & \multicolumn{2}{|c|}{$\mathbf{A}$} & \multicolumn{2}{|c|}{$\mathbf{U}$} & \multicolumn{2}{|c|}{ D } & \multicolumn{2}{|c|}{ SD } \\
\hline & $\mathbf{F}$ & $\%$ & $\mathbf{F}$ & $\%$ & $\mathbf{F}$ & $\%$ & $\mathbf{F}$ & $\%$ & $\mathbf{F}$ & $\%$ \\
\hline The system helps control pest and diseases. & 12 & 9.0 & 37 & 27.8 & 44 & 33.1 & 32 & 24.1 & 8 & 6.0 \\
\hline $\begin{array}{l}\text { The system allows for increased yam and yam } \\
\text { seedlings multiplication. }\end{array}$ & 24 & 18.0 & 80 & 60.2 & 23 & 17.3 & 4 & 3.0 & 2 & 1.5 \\
\hline The system requires less use of land. & 13 & 9.8 & 79 & 59.4 & 22 & 16.5 & 17 & 12.8 & 2 & 1.5 \\
\hline The system requires less use of labour. & 6 & 4.5 & 63 & 47.4 & 39 & 29.3 & 23 & 17.3 & 2 & 1.5 \\
\hline The system is a usable technology. & 11 & 8.3 & 93 & 69.9 & 22 & 16.5 & 7 & 5.3 & 0 & 0 \\
\hline The system has environmental benefits. & 11 & 8.3 & 87 & 65.4 & 33 & 24.8 & 2 & 1.5 & 0 & 0 \\
\hline The system is affordable. & 7 & 5.3 & 50 & 37.6 & 41 & 30.8 & 22 & 16.5 & 13 & 9.8 \\
\hline The system requires high cost of maintenance. & 24 & 18.0 & 79 & 59.4 & 15 & 11.3 & 14 & 10.5 & 1 & 0.8 \\
\hline The system requires high technical know-how. & 39 & 29.3 & 81 & 60.9 & 10 & 7.5 & 3 & 2.3 & 0 & 0 \\
\hline The system is highly complex. & 8 & 6.0 & 41 & 30.8 & 27 & 20.3 & 57 & 42.9 & 0 & 0 \\
\hline $\begin{array}{l}\text { The system ensures crops grow faster than any } \\
\text { other system. }\end{array}$ & 14 & 10.5 & 60 & 45.1 & 52 & 39.1 & 5 & 3.8 & 2 & 1.6 \\
\hline The system is stress free. & 5 & 3.8 & 64 & 48.1 & 63 & 32.3 & 21 & 15.8 & 0 & 0 \\
\hline
\end{tabular}

Source: research findings

Table 4: Perception of yam farmers about the aeroponics system.

use of land; the system requires less use of labour; the system is a usable technology; the system has environmental benefits; the system requires high cost of maintenance; the system requires high technical know-how; the system ensures crops grow faster than any other system; and the system is stress free. The remaining three statements were not favourably perceived by the respondents. These include: the system helps control pest and diseases; the system is affordable; and the system is highly complex.

The distribution of yam farmers by their willingness to adopt the aeroponics system as shown in Table 5 showed that seven out of ten respondents were willing to adopt the aeroponics system for yam and seed yam propagation despite earlier findings indicating a low level of awareness and a moderate level of perception. This indicates that apart from the availability of information, a farmer's decis ion/willingness to adopt is also influenced by other factors. These factors include: educational status, marital status, age of the farmer, farm size and access to credit, all of which can be grouped into three categories namely; economic, social and institutional factors.

\begin{tabular}{lcc}
\hline Response & Frequency & Percentage \\
\hline Yes & 95 & 71.4 \\
No & 38 & 28.6 \\
Total & 133 & 100.0 \\
Mean & 1.29 & \\
SD & 0.45 & \\
\hline
\end{tabular}

Source: research findings

Table 5: Willingness of yam farmers to adopt the aeroponics farming system.
The analysis of constraints faced by the yam farmers with respect to their willingness to adopt the aeroponics system revealed seven major constraints encountered by the farmers with respect to their willingness to adopt the aeroponics farming system as shown in Table 6. The mean of each constraint was determined by summing up the values picked by all the respondents and dividing by the total number of respondents. The most severe constraint faced by the respondents was high cost of capital required for adoption, followed by lack/inadequate information on aeroponics system and lack of access to credit facilities. On the other hand, the least severe constraints were the highly complex system and the tasking activities such as cleaning and spraying of nutrients involved in the aeroponics farming system.

Table 7 presents the results of the Logit regression analysis of the factors influencing the awareness of the yam farmers about the aeroponics farming system. The log-likelihood ratio following Greene (2011) was used to assess the overall significance of the model. The variance inflation factors (VIF) were used to inspect the level of multicollinearity between the independent variables. The Chi-square value of 29.90 and $\log$ likelihood value of -64.28 which are significant at $1 \%$ is an indication that the model is a good fit. The result shows that gender, age, educational status, cooperative value, income and access to extension agents were the explanatory variables that significantly affected farmers' awareness of the aeroponics farming system. Being a male farmer increased the likelihood of being aware of the aeroponics farming system 


\begin{tabular}{|c|c|c|c|}
\hline Constraints & Number & Mean & Rank \\
\hline High cost of capital required for adoption & 133 & 3.71 & 1 \\
\hline Lack / inadequate information on aeroponics system & 133 & 3.41 & 2 \\
\hline Lack of access to credit facilities & 133 & 3.07 & 3 \\
\hline The system requires technical know-how & 133 & 2.36 & 4 \\
\hline Lack of governmental support & 133 & 2.26 & 5 \\
\hline The system is highly complex & 133 & 2.19 & 6 \\
\hline $\begin{array}{l}\text { Activities involved in aeroponics system such as cleaning and spraying of } \\
\text { nutrient is tasking. }\end{array}$ & 133 & 1.60 & 7 \\
\hline
\end{tabular}

Source: research findings

Table 6: Constraints faced in willingness to adopt the aeroponics farming system.

\begin{tabular}{lccc}
\hline Explanatory variables & Coefficients & Marginal Effects & Z-value \\
\hline Gender & $0.0640^{* *}$ & 0.0148 & 2.17 \\
Age & $0.8107^{* * *}$ & 0.2552 & 3.58 \\
Marital status & -0.0366 & -0.0070 & -0.04 \\
Household size & 0.0023 & 0.0004 & 0.06 \\
Years of education & $-2.3231^{* *}$ & -0.1968 & -2.22 \\
Occupation & 0.4857 & 0.0839 & 0.65 \\
Access to credit & -0.3261 & -0.0589 & -0.49 \\
Cooperative society & $1.3129^{* *}$ & 0.2068 & 2.34 \\
Farm size & -0.0007 & -0.0001 & -0.03 \\
Income & $0.0000^{* * *}$ & $3.94 \mathrm{e}-06$ & 3.33 \\
Extension agent & $0.0917^{*}$ & 0.0116 & 1.85 \\
Yam farming experience & 0.0029 & 0.0005 & 0.13 \\
\hline
\end{tabular}

Note: *** and $* * *$ indicate significant at $10 \%, 5 \%$ and $1 \%$ significance levels respectively

McFadden Pseudo $\mathrm{R}^{2}=0.19$, Chi squared $=29.90$, Log likelihood function $=-64.28$

Source: research findings

Table 7: logit model estimation results of factors influencing yam farmers awareness of the aeroponics farming system.

by 0.014 unit. This could be attributed to the fact that males have better access to information on innovative farming technologies relative to their female counterparts (Obisesan, 2014). Also, the age of the yam farmers had a positive and significant effect on awareness of the aeroponics system. This implies that a year increase in the age of a yam farmer will increase the likelihood of the farmer's being aware by 0.255 unit. This is contrary to apriori expectations as younger farmers are expected to be more progressive and interested in searching out new technologies. In addition, income had a positive and significant influence on awareness. Specifically, a naira increase in the monthly income of the farmers will result in a 0.0004 unit increase in the level of awareness of the farmers. Access to extension agent had a positive effect on awareness. This implies that having access to an extension agent increased the likelihood of being aware of the aeroponics farming system by 0.116 units. Extension agents play a major role in providing support services for delivering improved agricultural information to the farmers. Hence, this study shows the importance of extension officers and confirms the findings of Ajewole (2010) who emphasized the importance of information dissemination channels and the ability of the farmers to process and make use of such information. Conversely, an additional year of education of the farmers decreased the likelihood of being aware of the aeroponics farming system by 0.1968 units. This might not be unconnected to the fact that higher education confers on the farmers the ability to better acquire, process, and use information relevant to the farming system. This finding is consistent with the findings of Meena and Punjabi (2012). In addition, membership of a cooperative society decreased the probability of awareness of the aeroponics system by 0.207 unit. This could be attributed to the fact that farmers who are members of one cooperative organisation or the other would have access to information on innovations through 
information disseminated in their respective cooperative organisations. This result corroborates the findings of Ilesanmi and Akinmusola (2016). Also, farmers in cooperative societies have more access to social capital enhancing trust, idea and information exchange (Mignouna et al., 2011).

The result of the logistic regression analysis of the factors influencing yam farmer's willingness to adopt the aeroponics farming system is presented in Table 8. The criterion used to assess the overall significance of the binary logit model was the log-likelihood ratio following Greene (2011). The variance inflation factors (VIF) were used to inspect the level of multicollinearity between the independent variables. The classification accuracy indicated the appropriateness of the model in predicting the adoption of the aeroponics farming system given the independent variables in question. A chi square value of $90.74(p<0.01)$ and $\log$ likelihood value of -33.86 thus indicate the goodness of fit of the model. Many of the explanatory variables have the expected signs and are statistically significant. Key positive determinants of farmers' willingness to adopt the aeroponics farming system include marital status, access to credit and extension agent, cooperative society, farm size, and income. However, the age of the yam farmer had negative effects. Marital status had a positive and significant effect on the willingness to adopt the aeroponics farming system. In other words, being married increased the likelihood of farmers' willingness to adopt the aeroponics system by 0.0115 unit. Married farmers are likely to have larger household sizes consisting of their wives and children who serve as a source of labour for activities in yam production (Okoffo et al., 2016). Also access to credit and membership of a cooperative society increased the log-likelihood of the willingness to adopt the aeroponics farming system by 0.0106 unit and 0.2662 unit respectively. Farmers with credit access are able to afford inputs required for the new technology. Also, credit can serve as a motivation towards adoption through the relaxation of rate of liquidity constraints as well as boosting of the farmer's risk bearing ability. This is in line with the findings of Ntshangase et al. (2018). In addition, the role of organizational membership in generating support for uptake of new innovation is that of information sharing and resource mobilization and higher market bargaining power (Ibitoye et al., 2013). Farm size was also positive implying that a hectare increase in farm size of farmers increased the likelihood of yam farmers' willingness to adopt the aeroponics farming system by 0.2865 unit. In other words, farmers with large farm sizes have the flexibility to adopt new technologies. This result corroborates the findings of Mignouna et al. (2011).

Furthermore, a positive and significant effect of monthly income on the willingness to adopt the aeroponics farming system implies that a naira increase in the income of farmers increased the likelihood that yam farmers would be willing to adopt the aeroponics system by 0.141 unit. This may be due to the fact that farmers with higher income would be able to buy inputs for farming and can afford new technologies (Ntshangase

\begin{tabular}{lccc}
\hline Explanatory variables & Coefficients & Marginal Effects & Z-value \\
\hline Gender & 2.0447 & 0.3376 & 0.87 \\
Age & $-0.1037^{* * *}$ & -0.0113 & -2.83 \\
Marital status & $1.9382^{*}$ & 0.0115 & 1.89 \\
Household size & 0.0195 & 0.0018 & 0.36 \\
Years of education & -1.0735 & -0.1255 & -1.01 \\
Occupation & 1.5352 & 0.2114 & 1.16 \\
Access to credit & $0.0599^{* *}$ & 0.0106 & 2.37 \\
Cooperative society & $2.8839^{* *}$ & 0.2662 & 2.28 \\
Farm size & $1.5970^{* *}$ & 0.2865 & 2.57 \\
Income & $0.6313^{*}$ & 0.1416 & 1.86 \\
Extension agent & $1.7877^{* *}$ & 0.0094 & 2.208 \\
Yam farming experience & -0.10411 & 0.0570 & 1.11 \\
\hline
\end{tabular}

Note: $* * *$ and $* * *$ indicate significant at $10 \%, 5 \%$ and $1 \%$ significance levels respectively

McFadden Pseudo $\mathrm{R}^{2}=0.58$, Chi squared $=90.74$, Log likelihood function $=-33.86$

Source: research findings

Table 8: logit model estimation results of factors influencing yam farmers willingness to adopt the aeroponics farming system. 
et al., 2018). On the other hand, the age of the farmer had a negative and significant effect on the willingness to adopt the aeroponics system. This implies that a year increase in age decreased the likelihood of adopting the aeroponics farming system by 0.0112 unit. This may be owing to the fact that older farmers are accustomed to and prefer the traditional system of yam production, and as a result are reluctant to adopt new technologies. Younger farmers on the other hand are usually more educated, knowledgeable and willing to bear risks involved with adopting agricultural innovations. This finding corroborates the findings of Okoffo et al., (2016). Extension services create the platform for acquisition of the relevant information that promotes technology adoption (Nadeeshani Silva and Broekel, 2016). Contact with extension agent also increased the likelihood of farmers' willingness to adopt the aeroponics farming system by 0.94 unit.

\section{Conclusion}

A major interest of policy makers in less developed countries is increased agricultural productivity to meet the rising demand for food with increase in population size. Agricultural productivity could however be improved if it is recognized that a key determinant of growth in productivity is the technology employed by the farmers. Evidence from many developing countries including Nigeria however reveal a low level of awareness of innovative technologies, such as the aeroponics farming system, required for increased agricultural productivity compared to developed countries. Farmers either do not adopt these technologies outrightly or their adoption of it is slow. Farmers' perception of the appropriateness of such improved technologies has been shown to be key to the adoption of the technology. Thus, efforts at ensuring effective dissemination of these technologies for effective adoption by farmers should be intensified to achieve the desired results.

Yam farming in Nigeria has been faced with a lot of constraints particularly the problem of obtaining seed yam for the cultivation of yam. This has resulted in the continuous drop in the national yam production over the years causing high cost of production and the inability to meet the demand for the fast-growing population and export standards. Based on the foregoing, this article examined the level of awareness and willingness to adopt the aeroponics farming system by yam farmers and identified the constraints inhibiting the adoption of the farming system by the farmers.
The result of the level of awareness of the farmers obtained with a likert scale indicate that majority of the respondents had never heard of the aeroponics system, while only a few had adequate information and hence were fully aware about the system for yam cultivation. Furthermore, examining the perception of the respondents towards the aeroponic system revealed that about threefifths of the respondents had a moderate perception about the system while only about one-quarter had a strong perception about the system. The respondents indicated that high cost of capital is the major constraint to the adoption of the aeroponic farming system by yam farmers, followed by lack of adequate information on the aeroponics farming system. While farmers' awareness of the aeroponics farming system was mainly influenced by gender, age, educational status, cooperative value, income and access to extension agents, factors influencing their willingness to adopt include marital status, age, access to credit, membership of cooperative society, farm size and income. This indicates that these factors should be the focus of development efforts for increased awareness and adoption of innovative technologies for improved agricultural productivity.

Based on the findings of this study, it is recommended that yam farmers be encouraged to organize themselves into groups, such as cooperative societies, while efforts at adequate farmer-extension contact should be intensified. This is to allow for quicker and easier dissemination of information pertaining to agricultural innovations and technologies most especially the benefits of adopting such new technologies and its positive effect on their productivity. The study identifies the constraints to adoption of a new agricultural technology despite the expected benefits from the adoption of it. Thus, efforts towards the availability and accessibility of credit facilities to farmers, most especially to small-scale farmers, to reduce the high cost of capital constraint encountered by the farmers, in the adoption of new technology should be a major policy thrust of government. The study showed that higher levels of education increased farmers' likelihood of awareness of the aeroponics farming system. In view of this, policy measures targeted towards improvement in human capital development of the farmers is key to the adoption of new technologies. 
Corresponding authors

Abimbola Oluyemisi Adepoju, Ph.D.

Department of Agricultural Economics, Faculty of Agriculture,

University of Ibadan, Ibadan, Oyo State, Nigeria

Phone:+2348033335958,E-mail: abimbola.adepoju@yahoo.com

\section{References}

[1] Aighewi, B., Asiedu, R., Maroya, N. and Balogun, M. (2015) "Improved propagation methods to raise the productivity of yam (Dioscorea rotundata Poir.)", Food Security, Vol. 7, pp. 823-834. ISSN 1876-4517. DOI 10.1007/s12571-015-0481-6.

[2] Ajewole, O. (2010) "Farmer's response to adoption of commercially available organic fertilizers in Oyo state, Nigeria”, African Journal of Agricultural Research, Vol. 5, No. 18, pp. 2497-2503. ISSN 1991-637X.

[3] Awoniyi O. and Omonona, B. T. (2007) "Production Efficiency in Yam Based Enterprises in Ekiti State, Nigeria", Journal of Central European Agriculture, Vol. 7, No. 4, pp. 627-636. ISSN 13329049.

[4] Bagheri, A. (2010) "Potato farmers' perceptions of sustainable agriculture: the case of Ardabil province of Iran", Procedia Social and Behavioral Sciences, Vol. 5, pp. 1977-1981. ISSN 1877-0428. DOI 10.1016/j.sbspro.2010.07.399.

[5] Bassey, E. E. (2017) "Constraints and prospects of yam production in Nigeria”, European Journal of Physical and Agricultural Sciences, Vol. 5, No. 1, pp. 55-65. ISSN 2056-5879.

[6] Chukwu, G. and Ikwelle, M. (2000) "Yam: Threats to its sustainability in Nigeria", Palawija News, Indonesia, The CGPRT Newsletter Vol. 17, No. 1, pp. 1-7.

[7] Cohen, J. (2003) "Human Population: The Next Half Century", in: Little, J. S, Triest, R. K, editors. "Seismic shifts: the economic impact of demographic change", Federal Reserve Bank. [Online]. Available: http:// www.sciencemag.org [Accessed: 20 Mar. 2019].

[8] Edeoghon, C. O., Ajayi, M. T. and Ugboya, T. O. (2008) "Awareness and use of sustainable agricultural practices by arable crop farmers in Ikpoba Okha local government area of Edo State", Journal of Sustainable Development in Agriculture \& Environment, Vol. 3, No. 2, pp. 55-63. ISSN 0794-8867.

[9] FAO (2013) Food and agricultural organization of the United Nations. [Online]. www.fao.org/ statistics/en/ FAO, Rome [Accessed: 15 Mar. 2019].

[10] Greene, W. (2011) "Econometric analysis", $7^{\text {th }}$ edition, Upper Saddle River, New Jersey, Prentice Hall Publishers. ISBN 13 978-0131395381.

[11] Ibitoye, S. and Onimisi, J. A. (2013) "Economic assessment of yam production in Kabba- Bunu Local Government Area of Kogi State, Nigeria”, Journal of Development and Agricultural Economics, Vol. 5, No. 11, pp. 470-475. ISSN 2006-9774. DOI 10.5897/JDAE2013.0484.

[12] Idumah, F. O., Owombo, P. T. and Ighodaro, U. B. (2014) "Economics of yam production under agroforestry system in Sapoba Forest Area, Edo State, Nigeria”, International Journal of Agriculture and Forestry, Vol. 4, No. 6, pp. 440-445. E-ISSN 2165-8846, ISSN 2165-882X.

[13] IITA (International Institute for Tropical Agriculture) (2009) "Yam (Dioscorea species)". [Online]. Available: http://www.iita.org/yam [Accessed: 12 Feb. 2019].

[14] Ilesanmi, R. and Akinmusola, O. (2016) "Factors Limiting the Yam Minisett Technique Adoption: A Review", Agricultural Research Communication Centre, Vol. 37, No. 3, pp. 213-220. E-ISSN 0976-0539, ISSN 0253-1496. DOI 10.18805/ar.v0i.11285.

[15] Katung, P. S., Idem, N. U. and Onyibe. J. E. (2006) "Yam, in: Idem, N. U. A and Showemino, F. A. (eds) "Tuber and fibre crops of Nigeria: Principles of production and utilization", Ade Commercial Press, Zaria, Nigeria, pp. 45-62. 
[16] Kolawole, A., Oladele, O.I., Alarima, C. I. and Wakatsuki, T. (2012) 'Farmers' perception of Sawah rice production technology in Nigeria, Journal of Human Ecology, Vol. 37, No. 1, pp.13-17. ISSN 09709274.

[17] Manyong, V. M., Asiedu, R. and Olaniyan, G. O. (2001) "Farmers perception of and actions on, resources management constraints in the yam based systems of Western Nigeria" in: Akoroda, M.O. and Ngeve, J. M. (compilers) "Root Crops in the $21^{\text {st }}$ century", Proceeding of the $7^{\text {th }}$ Triennial Symposium of the International society for Tropical Root Crops-African Branch, held at the Centre of International Conferences, Cotonou, Benin, Vol. 117, pp. 156-167.

[18] Maroya, N., Balogun, M. and Asiedu, R. (2014) "Seed Yam Production in an Aeroponics", IITA -YIIFSWA Working Paper Series, No 2., Institute International of Tropical Agriculture, Ibadan, Nigeria. $9 \mathrm{p}$.

[19] Meena, G . and Punjabi, N. (2012) "Farmer's Perception towards Agriculture Technology in Tribal Region of Rajasthan", Rajastan Journal of Extension Education, Vol. 20, pp. 92-96. ISSN 0973-1113.

[20] Mignouna, D., Manyong, V. A. and Rusike, J. (2011) "Deteminants of Adopting Imazapyr-Resistant Maize Technologies and its Impact on Household Income in Western Kenya", AgBioForum, Vol. 14, No. 3, pp. 158-163. ISSN 1522936X.

[21] Mottaleb, K. A. (2018) "Perception and adoption of a new agricultural technology: Evidence from a developing country", Technology in Society, Vol. 55, pp.126-135. ISSN 0160-791X. DOI 10.1016/j.techsoc.2018.07.007.

[22] Mukadasi, B. and Lusiba, B. (2006) "Farmers' perception of relevance of agricultural technologies under plan for modernization of agriculture in Uganda", Uganda Journal of Agricultural Sciences, Vol. 12, No. 2, pp. 7-15. ISSN 1026-0919.

[23] Nadeeshani, S. K. and Broekel, T. (2016) "Factors constraining farmers adoption of new agricultural technology programme in Hambantota District in Sri Lanka: perceptions of agriculture extension officers", University of Sri Jayewardenepura, Sri Lanka, $13^{\text {th }}$ International Conference on Business Management (ICBM) 2016.

[24] Nain, M. S., Singh, R. and Mishra, J.R. (2017) “A Study of Farmers' Awareness on Agricultural Insurance Schemes in Southern Haryana”, Indian Journal of Extension Education, Vol. 53, No. 4, pp. 75-79. ISSN 0537-1996.

[25] Ntshangase, N., Muroyiwa, B. A. and Sibanda, M. (2018) "Farmers' Perceptions and Factors Influencing the Adoption of No-Till Conservation Agriculture by Small-Scale Farmers in Zashuke, KwaZulu-Natal Province", University of Sri Jayewardenepura, Sri Lanka, 13 ${ }^{\text {th }}$ International Conference on Business Management (ICBM) 2016. DOI 10.3390/su10020555.

[26] Obisesan, A. (2014) "Gender Differences in Technology Adoption and Welfare Impact Among Nigerian Farming Households", Munich Personal RePEc Archive, (58920). [Online]. Available: https://mpra.ub.uni-muenchen.de/58920/. [Accessed: 25 Feb. 2019].

[27] Ochola, D., Jogo, W., Ocimati, W., Rietveld, A., Tinzaara, W., Karamura, D. and Karamura, E. (2013) 'Farmers' awareness and perceived benefits of agro-ecological intensification practices in banana systems in Uganda", African Journal of Biotechnology, Vol. 12, No. 29, pp. 4603-4613. ISSN 1684-5315.

[28] Okoffo, E. Denkyirah, E., Adu, D. and Fosu-Mensah, B. (2016) “A double - hurdle model estimation of cocoa farmers' willingness to pay for crop insurance in Ghana”, SpringerPlus, Vol. 5, Article No. 873. DOI 10.1186/s40064-016-2561-2.

[29] Oladele, O. I. and Fawole, O. P. (2007) "Farmers perception of the relevance of agriculture technologies in south-western Nigeria”, Journal of Human Ecology. Vol. 21, No. 3, pp. 191-194. E-ISSN 2456-6608, ISSN 0970 9274. DOI 10.1080/09709274.2007.11905971.

[30] Osvald, J., Petrovic, N., and Demsar, J. (2001) "Sugar and Organic Acid Content of Tomato Fruits (Lycopersicon lycopersicum mill.) Grown on Aeroponics at Different Plant Density", Acta Alimentaria, Vol. 30, No. 1, pp. 53-61. E-ISSN 01393006, ISSN 15882535. DOI 10.1556/AAlim.30.2001.1.6. 
[31] Simtowe, F., Muange, B., Munyua, B. and Diagne, A. (2012) "Technology awareness and adoption: the case of improved pigeonpea varieties in Kenya", International Association of Agricultural Economists, No 126760, Conference, August 18-24, 2012, Foz do Iguacu, Brazil.

[32] Udimal, T. B., Jincai, Z., Mensah, O. S. and Caesar, A. E. (2017) "Factors influencing the agricultural technology adoption: the case of improved rice varieties (Nerica) in the Northern Region, Ghana", Journal of Economics and Sustainable Development, Vol. 8, No. 8, E-ISSN 2222-2855, ISSN 2222-1700.

[33] Urquhart, J., Potter, C., Barnett, J., Fellenor, J., Mumford, J., Quine, C. and Bayliss H. (2017) "Awareness, concern and willingness to adopt biosecure behaviours: public perceptions of invasive tree pests and pathogens in the UK", Biological Invasions, Vol. 19, No. 9, pp. 2567-2582. ISSN 1387-3547. DOI 10.1007/s10530-017-1467-4.

[34] Verter, N. and Bečvářová, V. (2015) "An analysis of yam production in Nigeria", Acta Universitatis Agriculturae et Silviculturae Mendelianae Brunensis, Vol. 63, No. 2, pp. 659-665. E-ISSN 2464-8310, ISSN 1211-8516. DOI 10.11118/actaun201563020659.

[35] Yamane, T. (1967) "Statistics, an introductory analysis", $2^{\text {nd }}$ Ed., New York: Harper and Row, p. 919. 